BULLETIN OF PNRPU. GEOLOGY. OIL \& GAS ENGINEERING \& MINING

ВЕСТНИК ПНИПУ. ГЕОЛОГИЯ. НЕФТЕГАЗОВОЕ И ГОРНОЕ ДЕЛО

ISSN 2224-9923

Volume / TOM 15 №19 2016

http://vestnik.pstu.ru/geo/

УДК 552.578

Article / Статья

(C) PNRPU / ПНИПУ, 2016

\title{
LITHOLOGICAL FEATURES OF COAL-OVERLYING ACCUMULATIONS OF UPPER VASIUGAN FORMATION OF KAZAN OIL-GAS-CONDENSATE FIELD
}

\section{K.V. Gabova}

TomskNIPIneft JSC (72 Mira av., Tomsk, 634027, Russian Federation)

\section{ЛИТОЛОГИЧЕСКИЕ ОСОБЕННОСТИ ПРОДУКТИВНЫХ ОТЛОЖЕНИЙ НАДУГОЛЬНОЙ ПАЧКИ ВЕРХНЕВАСЮГАНСКОЙ ПОДСВИТЫ В ПРЕДЕЛАХ КАЗАНСКОГО НЕФТЕГАЗОКОНДЕНСАТНОГО МЕСТОРОЖДЕНИЯ}

\author{
К.В. Габова \\ ОАО «ТомскНИПИнефть» (634027, Россия, г. Томск, пр. Мира, 72)
}

Received / Получена: 09.03.2016. Accepted / Принята: 25.04.2016. Published / Опубликована: 30.06.2016

\section{Key words:}

Kazan oil-gas-condensate field, coal-overlying set, Upper Vasiugan formation, reservoirs, matter composition, cement, secondary transformation, diagenesis, katagenesis.
Ключевые слова:

Казанское нефтегазоконденсатное месторождение, надугольная пачка, верхневасюганская подсвита, коллекторы, вещественный состав, цемент, вторичные преобразования, диагенез, катагенез.
The study of secondary transformations of accumulation has to be an integral component of modern lithological study because it allows understanding all the features of stages of processes that form accumulation and transform sedimetary rocks. This is essential in prediction of areas with better reservoir properties. In order to find features of reservoir rocks and its influence on reservoir properties the author conducted a detailed lithological study of accumulation of coal-overlying set of Upper Vasiugan formation of Kazan field. In terms of regional tectonics the field is located in central part of Kazan dome dedicated to local upheaval that is located on the east part of Niurol depression. As an object to study it was decided to choose deposits of coaloverlying set of Upper Vasiugan formation which cross-section includes sand layers $\mathrm{J}_{1}^{1}$ and $\mathrm{J}_{1}^{2}$.

This paper presents results of the study of composition of rock-forming and cementing matter of productive layers $J_{1}^{1}$ and

$\mathrm{J}_{1}^{2}$ of Kazan oil-gas-condensate field (Tomsk region). Studies showed that nature of reservoir properties of silty-sand rocks are mainly determined not only by sedimentation conditions, but nature of post-sedimentary changes as well. During the study of rock thin sections diagenetic and katagenetic indicators of lithogenesis are found. In order to determine causes of irregular porosity and permeability distribution along a thin section dependency of these properties on both primary (sedimentation) and secondary (post-sedimentation) factors were found. To find the answer for this challenge the author determined pair correlation coefficients and built diagrams. As a result of the study parameters that improve and deteriorate reservoir properties of sandstones of Kazan deposits were identified.

Изучение вторичных изменений продуктивных отложений должно являться неотъемлемой составляющей современного литологического исследования, так как оно позволяет понять многие особенности стадийности процессов формирования залежи и преобразования осадочных горных пород. Это имеет существенное значение при прогнозировании зон с улучшенными коллекторскими свойствами. Автором проведены детальные литологические исследования продуктивных отложений надугольной пачки верхневасюганской подсвиты нефтегазоконденсатного Казанского месторождения с целью выявления особенностей пород-коллекторов и влияния этих особенностей на фильтрационноемкостные свойства. В регионально-тектоническом отношении месторождение находится в центральной части Казанского куполовидного поднятия, приурочено к одноименному локальному поднятию, расположенному в восточной части Нюрольской впадины. Объектом исследования были выбраны отложения надугольной пачки верхневасюганской подсвиты, разрез которой включает в себя продуктивные песчаные пласты $Ю_{1}^{1}$ и $Ю_{1}^{2}$.

В работе приводятся результаты исследования вещественного состава породообразующей части и цементирующего материала продуктивных пластов $Ю_{1}^{1}$ и $Ю_{1}^{2}$ Казанского нефтегазоконденсатного месторождения (Томская область). Как показали исследования, характер фильтрационно-емкостных свойств алевропесчаных пород во многом определяется не только условиями осадконакопления, но и характером постседиментационных изменений. При изучении петрографических шлифов были отмечены минеральные индикаторы как диагенетической, так и катагенетической стадий литогенеза. Для выяснения причины неравномерности распределения пористости и проницаемости по разрезу были выявлены зависимости этих свойств как от первичных (седиментационных), так и от вторичных (постседиментационных) факторов. Для решения данной задачи были рассчитаны парные коэффициенты корреляции и построены диаграммы. В результате проведенных исследований были выявлены параметры, улучшающие и ухудшающие коллекторские свойства песчаников Казанского месторождения.

Ksenia V. Gabova - Junior Researcher (mob. tel.: +007 382261 19 65, e-mail: GabovaKV@ nipineft.tomsk.ru).

Габова Ксения Валерьевна - младший научный сотрудник (моб. тел.: +007 382261 19 65, e-mail: GabovaKV@nipineft.tomsk.ru). 


\section{Inroduction}

Study of secondary change of accumulation should be an integral component of modern lithological research because it allows understanding many features of staging of processes that form deposits and transform sedimentary rocks. It is essential in prediction of areas with better reservoir properties. Challenges of sedimentary rock transformations are studied by lots of scientists such as N.M. Strakhov, O.V. Iapaskurta, R.S. Sakhibgareeva etc. Z.Ia. Serdiuk, E.A. Predtechenskaia, N.M. Nedolivko contributed a lot to the study of secondary transformations of clastic rocks in West Siberia. Stage transformations affect foremost properties of mineral rock components and then on reservoir properties of reservoirs itself.

In order to identify characteristics of reservoir rocks and its influence on reservoir properties the author conducted a detailed lithological research of coal-overlying accumulation of Upper Vasiugan formation of Kazan oil-gas-condensate field. Objectives of the study were to determine material composition of detritus part and cement material of sand rocks in thin sections, their particle size composition and to analyze obtained data distribution across well cross-sections.

Kazan oil-gas-condensate field is located on Parabel territory of Tomsk region. In terms of regional tectonics the field is located in central part of Kazan dome dedicated to local upheaval of the same name that is located on the east part of Niurol depression. Geological structure of the field is dedicated to Paleozoic, Mesozoic and Cenozoic age. Material composition of the pre-Jurassic basement rocks contain greenstone altered plagioclase porphyrites, dolomitized limestones and metamorphosed sandstones. The cross-section of sedimentary cover rocks begins from Jurassic age, presented by Tyumen, Vasiugan, Georgiev and Bazhenov formations [1]. The objects of research were coal-overlying accumulation of Upper Vasiugan formation, which crosssection includes sand reservoirs $\mathrm{J}_{1}^{1}$ and $\mathrm{J}_{1}^{2}$.

\section{Petrographic analysis of sand rocks of coal-overlying set of Kazan field}

Detailed petrographic analysis of thin sections of sand rocks was performed on a polarizing microscope Olympus BX51 by conventional techniques [2-14]. When describing thin sections material composition and pore space were studied. Material composition includes detritus part with rock forming, accessory minerals, authigenic minerals and cement, organic matter and other organic residues. Content of these components are hereinafter given as a percentage of total area of the section.

Sediments of reservoir $\mathrm{J}_{1}^{1}$ are studied on 26 thin sections from 8 wells of Kazan oil-gas-condensate field (Table 1). According to particle size distribution they are presented by fine-grain to finemedium-grain sandstone and medium-coarse-grain rarely. Sort in most cases is good and very good, medium sort is less common. Debris have angular to subrounded shape. Most microtexture of rocks is homogeneous.

According to the classification of V.D. Shutov reservoir $\mathrm{J}_{1}^{1}$ sandstones are medium-grain quartzose and rarely quartz feldspar in mineral composition (Fig. 1). The content of rock-forming minerals is $61-84 \%$ of total rock volume. Quartz is found as fragments of different shapes, which are rarely corroded in poor to moderate level. Recovery is expressed in clear dashed hems and partially restored crystallographic faces (Fig. 2) and is found in the range from poor to strong.

Feldspars are presented by potassium feldspar (PF) and plagioclase (intermediate and acid composition), which are slightly pelletized. Individual grains are pelletized more intense, sericitized and dissolved in the range from poor to strong. Rock debris are presented by silica, mica, silica-mica rocks, volcanic rocks of different composition, granitoids, clay and mica-clay rocks, myrmekites, micropegmatites, perthite, single grains of chlorites. 
Table 1 - The main lithological characteristics of sandstone reservoirs $\mathrm{J}_{1}^{1}$ and $\mathrm{J}_{1}^{2}$

\begin{tabular}{|c|c|c|c|}
\hline & \multirow{2}{*}{ Sandstone property } & \multicolumn{2}{|c|}{ Average value in formation } \\
\hline & & $\mathrm{J}_{1}^{1}$ & $\mathrm{~J}_{1}^{2}$ \\
\hline \multicolumn{2}{|c|}{ Weighted average diameter, mm } & $0.29(0.17-0.42)$ & $0.18(0.10-0.27)$ \\
\hline \multicolumn{2}{|c|}{ Sort } & 1.37 & 1.88 \\
\hline \multirow{3}{*}{ Composition, \% } & quartz & $67(60-75)$ & $44(19-69)$ \\
\hline & feldspars & $18(13-24)$ & $24(12-36)$ \\
\hline & rock debris (including mica) & $15(7-24)$ & $29(15-43)$ \\
\hline \multicolumn{2}{|l|}{ Pore size, mm } & $\begin{array}{c}0.25(0.01-0.50) \\
\text { Rarely } 0.7-1.0\end{array}$ & $\begin{array}{l}0.13 \text { (0.02-0.25), } \\
\text { Rarely up to } 0.35\end{array}$ \\
\hline \multirow{5}{*}{ Cement, \% } & calcite & $1.45(0.8-2.1)$ & $1.10(0.4-1.8)$ \\
\hline & kaolinitic & $9.80(2.4-17.2)$ & $4.95(0.3-9.6)$ \\
\hline & hydromica & $3(0.6-5.4)$ & $7.0(1.0-13.0)$ \\
\hline & siderite & $1.3(0.5-2.1)$ & $1.95(0.1-3.8)$ \\
\hline & chlorite & $0.85(0.5-1.2)$ & $0.90(0.3-1.5)$ \\
\hline \multicolumn{2}{|l|}{ Cement type } & Pore, film-pore & Pore, film-pore \\
\hline \multicolumn{2}{|l|}{ Organic matter } & $1(0.5-1.5)$ & $1.05(0.1-2.0)$ \\
\hline \multicolumn{2}{|c|}{ Microtexture } & Homogeneous & Oriented, homogeneous \\
\hline \multicolumn{2}{|c|}{ Porosity (thin sections), \% } & $15.6(8.3-22.9)$ & $11.05(5.3-17.0)$ \\
\hline \multicolumn{2}{|c|}{ Effective gas porosity $\left(K_{p o}, \%\right)$} & $20.2(17.2-23.2)$ & 16.45 (13.0-19.9) \\
\hline \multicolumn{2}{|c|}{ Absolute gas permeability $\left(K_{p}, 10^{-3} \mu \mathrm{m}^{2}\right)$} & $136.7(4.4-513.4)$ & $22.4(0.2-147.1)$ \\
\hline
\end{tabular}

Note. There are maximum and minimum values presented in brackets.

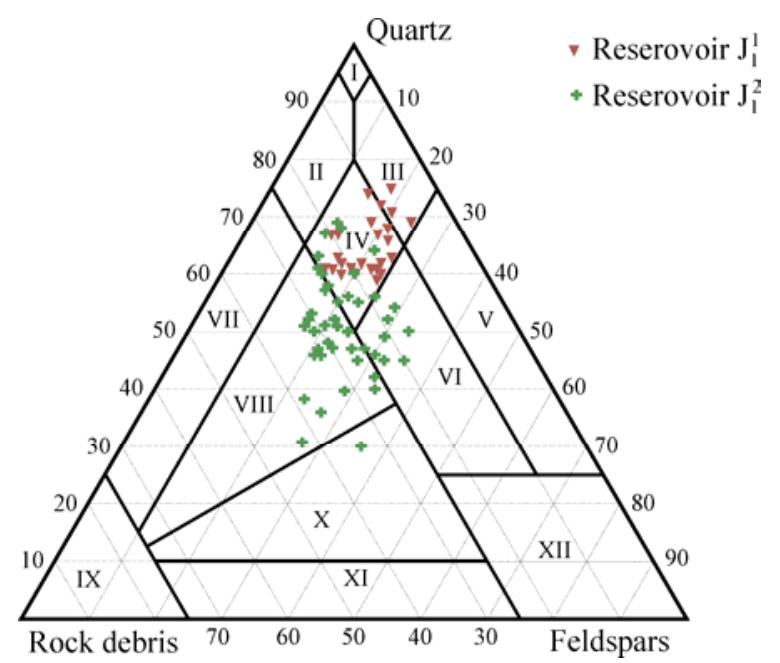

Fig. 1. Classification diagram of V.D. Shutov with figurative points of sandstone compositions for reservoirs $\mathrm{J}_{1}^{1}$ and $\mathrm{J}_{1}^{2}$ : I - quartz-monomictic sandstons; II - flint-quartz sandstone; III - feldspar-quartz sandstones; IV - monomictic quartz sandstones; V - arkose sandstones; VI - graywacke arkoses; VII - quartz greywackes; VIII - feldspar-quartz greywackes; IX - greywackes; X - quartz-feldspar greywackes; XI - feldspar; XII - sandstones of nonclastic origin. Field numbers on diagram are marked by Arab numerals

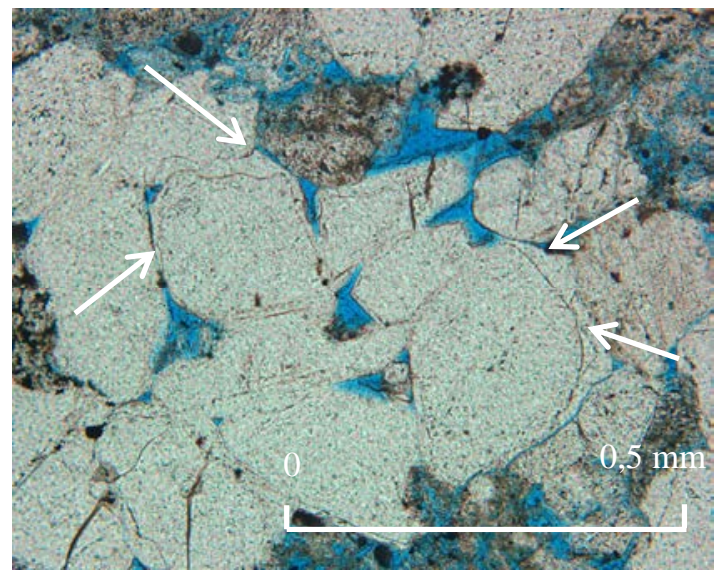

Fig. 2. Regeneration hems on quartz grains (pointed by arrows). Well 113 of Kazan field, reservoir $\mathrm{J}_{1}^{1}$, depth from well logging is $2572.96 \mathrm{~m}$. Nicols are parallel

The content of mica (biotite and muscovite) is $0.1-1.6 \%$. Rocks have poor to moderate sealing. Most spread intergranulaer contact are as follows: isolated and spot; linear, conformal and incorporated are subordinated (Fig. 3). 
Rocks contain accessory minerals such as epidote, zircon, sphene, hornblende, apatite, clinozoisite. Authigenic minerals are presented by pyrite (from single seeds to $1.5 \%$ ), leucoxene (rare films and up to $0.3 \%$ ), well rounded single glauconite grains (up to $0.8 \%$ ).

Pyrite occurs in the form of globules and their intergrowths, fine-grained aggregates as well as

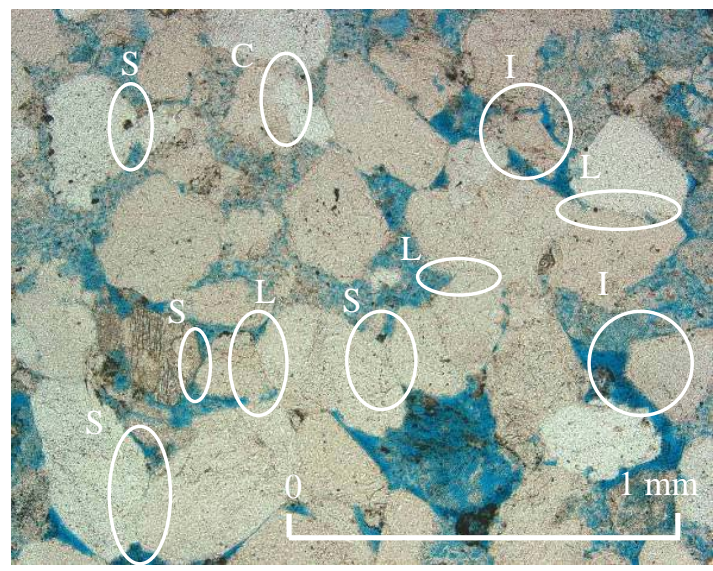

Fig. 3. Different types of intergranular contacts in finegrained sandstone: S - spot, L - linear, C - conformal, $\mathrm{I}$ - isolated. Well 663 of Kazan field, reservoir $\mathrm{J}_{1}^{1}$, depth from well logging is $2633,50 \mathrm{~m}$. Nicols are parallel small rash, crystalline aggregates of cubic form sometimes in association with organic matter.

Clay and carbonate rock cement is distributed unevenly. Pore clay cement presented by kaolinite, filmpore (hydromica) (Fig. 4) and chlorite, which confirms $\mathrm{X}$-ray phase analysis of clay fraction (Table 2). Calcite cement of pore type is rare (poikilitic, basal).

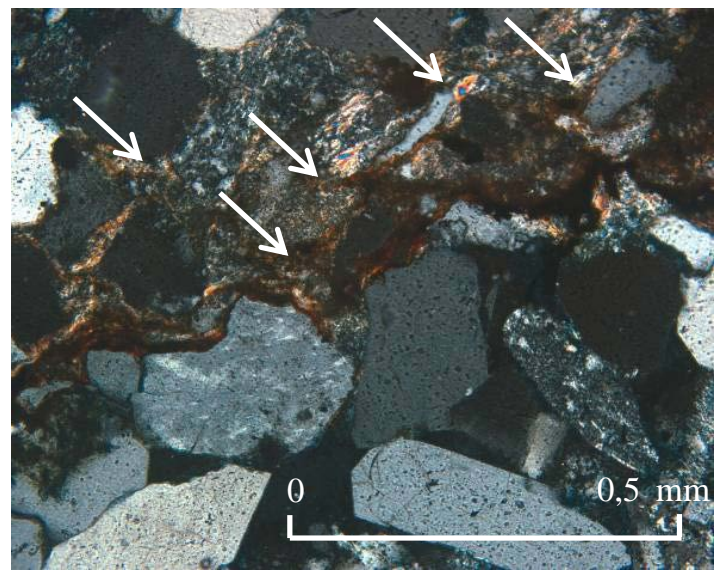

Fig. 4. Film-pore hydromica cement (pointed by arrows) in association with organic matter. Well 122 of Kazan field, reservoir $\mathrm{J}_{1}^{2}$, depth from well logging is 2511,77. Nicols are crossed

Table 2 - Material composition of clay component of sediments from layers $\mathrm{J}_{1}^{1}$ and $\mathrm{J}_{1}^{2}$ based on the results of X-ray tomography analysis

\begin{tabular}{|c|c|c|c|c|c|c|}
\hline \multirow{2}{*}{ № of sample } & \multirow{2}{*}{ Reservoir } & \multirow{2}{*}{ Depth, m } & \multicolumn{4}{|c|}{ Clay minerals, \% } \\
\hline & & & Kaolinite & Chlorite & Hydromica & $\Sigma \%$ \\
\hline 1 & \multirow{4}{*}{$\mathrm{J}_{1}^{1}$} & 2562.59 & 79 & 9 & 12 & 100 \\
\hline 2 & & 2564.66 & 77 & 10 & 13 & 100 \\
\hline 3 & & 2566.81 & 80 & 9 & 11 & 100 \\
\hline Average & & & 79 & 9 & 12 & \\
\hline 1 & \multirow{5}{*}{$\mathrm{J}_{1}^{2}$} & 2578.32 & 52 & 12 & 36 & 100 \\
\hline 2 & & 2583.09 & 64 & 10 & 26 & 100 \\
\hline 3 & & 2584.82 & 61 & 10 & 29 & 100 \\
\hline 4 & & 2586.62 & 55 & 12 & 33 & 100 \\
\hline Average & & & 58 & 11 & 31 & \\
\hline
\end{tabular}

Corrosion and partial replacement of detrital grains by calcite is observed. Pelitomorphic and fine-graine siderite is distributed unevenly in the sandstone. More often it is presented as segregations of long and complex form. The size exceeds size of detritus grains and sometimes fills intergranular space.
Organic matter is represented by brownishred translucent and dark brown streaks; misshapen elongated inclusions, heterogeneous clusters of unusual shape, sometimes in association with pyrite.

Furthermore, there is in thin sections brown and brownish-yellow oil substance which impreg- 
nates clay cement, mica or mica and clayking aggregates and fragments partially, and forms films and smears in pores.

Plant detritus is rare. Inclusion of up to $0.25 \mathrm{~mm}$ of elongated and isometric form crosslinked, brownish-black in association with pyrite.

Porosity, determined on thin sections, is 8.3-22.9\%. Intergranular communicating semiisolated and isolated pores of isometric, triangular, angular, slit-like, bay-sized and complex form of 0.01-0.50 mm, rare up to 0.7-1.0 mm. Multiple interagregate micropores are presented in kaolinate cement (Fig. 5), intragranular dissolution of feldspars and rock debris. Voids are often unevenly distributed.

Calcitized bivalve shell fragments of up to $0.42 \mathrm{~mm}$ in diameter and greater than $1 \mathrm{~mm}$ in length.

Sand deposits of formation $\mathrm{J}_{1}^{2}$ studied in 49 thin sections of 11 wells (see Table 1 ). Rock structure is mainly fine-grain, rare medium-fine grain, singularly different grain. Grains are sorted good, moderate sort is rare, in singular events sort is bad and very good. According to composition of the reservoir and classification of V.D. Shutov sandstones are feldspar-quartz greywacke and rare mezomict quartz and greywacke arkose sandstones (see Fig. 1). Rock microtexture are mainly microlayered, oriented, rare homogeneous. Microlayerd and oriented textures are caused by subparallel orientation of elongated

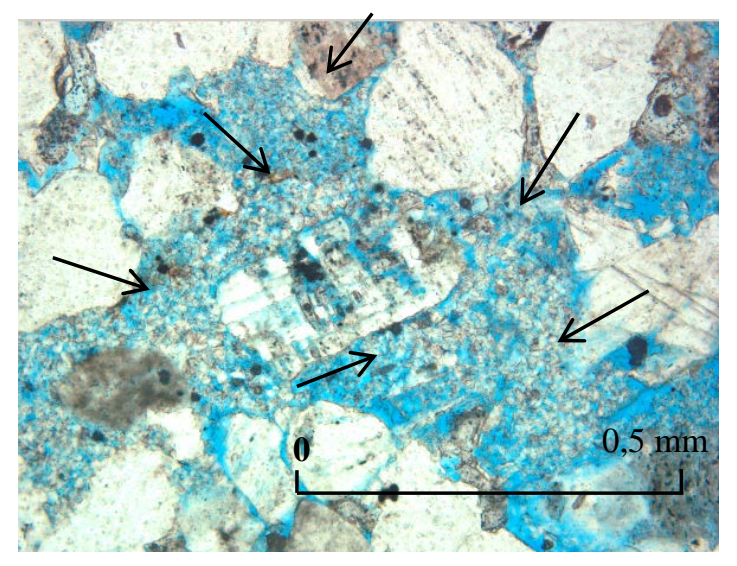

Fig. 5. Micropores in kaolinite cement (pointed by arrows).

Well 113 of Kazan field, reservoir $J_{1}^{1}$, depth from the well logging is $2576.25 \mathrm{~m}$. Nicols are parralel grains, flakes of mica, segregations of fine-graine and pelitomorphic siderite, which is often concentrated in poorly highlighted layers, sometimes streaked with organic matter and plant detritus.

The amount of rock forming minerals is 72.091.0\% of thin section area. Quartz grains have wavy and straight extinction, regeneration is represented in poor to moderate level. Its crystallographic faces are partially restored and clear dashed hems. Feldspars are presented by Plagioclase (mainly medium and acid) and PF. They are characterized by following secondary transformation: sericitization, pelitization and dissolution represented in poor to moderate extent. Regeneration of feldspars occurs rare. Debris rocks are presented by mica and silica-mica rocks (often with fuzzy borders), clastic, volcanic rocks, clay, mirmekites, single micropegmatits and chlorite grains. Muscovite is presented in an amount of 0.1$1.2 \%$, biotite is presented in $0.2-0.6 \%$. Rocks are bounded from moderate to strong extent. Isolated, spot and linear, incorporated rarely are presented among intergranular contacts. Accessory minerals are as follows: sphene, zircon, clinozoisite, apatite, ilmenite, tourmaline, magnetite, chromite, ilmenite and titaniferous minerals. As authigenic minerals there is pyrite presented by $5.2 \%$ of crystal aggregates that have cubic shape, dense and elongated additives, dispersed globules and its small intergrowths and by rash. It is often developed on inclusions of plant detritus. Glauconite is rare and has single hemigrained grains. Leucoxene forms rare films around grains and is presented by amount of $0.3 \%$.

Cement is polimeral in the rocks and is spread unevenly. Main components cement are secondary minerals, which are represented mainly by kaolinite (pore distribution type) and hydromica (filmpore distribution) (see Table 2), rarely by calcite, siderite and chlorite. Siderite grained, pelitomorphic often developed by the fragments, in cement. In addition, there are separations of up to $0.4 \mathrm{~mm}$ in length.

Organic matter are presented by red-brown and dark-brown spots of unusual shape and heterogeneous accumulations. It is translucenced on 
borders, pyritized by zones, partially impregnates and pigments of hydromica cement and debris form films and pore smears. Plant detritus are rare (up to $2.5 \times 3.0 \mathrm{~mm}$ ) as well as elongated and isometric form with a cell of up to 2-3 $\mathrm{mm}$ of black, reddish-black, yellow color in association with pyrite and hydromica in an amount of $10 \%$.

Porosity is formed by intergranular interconnected pores of slotted, angular or complex form of isolated or hemi-isolated with a size of $0.02-0.25 \mathrm{~mm}$ and rare $0.35 \mathrm{~mm}$. There are micropores in clay cement, intragrain pores dissolution of feldspars (Fig. 6) and debris. Voids are often distributed unevenly.

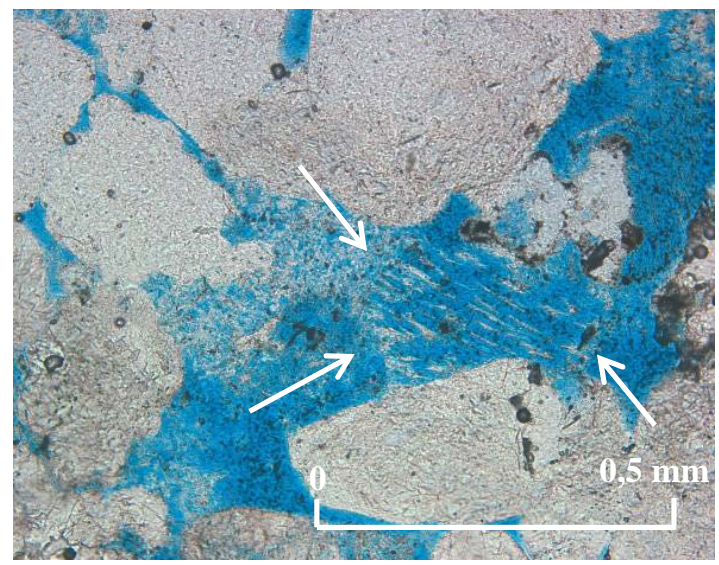

Fig. 6. Pores of dissoluted feldspars (pointed by arrows). Well 663 of Kazan field, reservoir $\mathrm{J}_{1}^{1}$, Depth from well

logging is 2633.49 м. Nicols are parallels

Several tooth-hump stylolite formations with low amplitude that are made both from clay and organic matter together in association with plant detritus are presented.

\section{Influence of sedimentation and post-sedimentation transformations on reservoir properties}

Based on the data, given by a laboratory of petrophysics of TomskNIPIneft JSC gas porosity in samples $\left(K_{p o}\right)$ is relatively stable and varied in a small range unlike $\left(K_{p}\right)$, which values change in a wide range. Sandstones of $\mathrm{J}_{1}^{1}$ and $\mathrm{J}_{1}^{2}$ layers are reservoirs of pore type and have moderate to low volume capasity. According to the classification of
A.A. Khanin they have III and IV class respectivelly [15].

In order to determine a reason for uneven distribution of rock porosity and permeability in cross-section it is needed to determine their relationship on primary and secondary factors [16-22]. Study shows that a character of reservoir properties of silt-sand rocks are significantly determined by both sedimentation conditions and character of post-sedimentation transformations.

As primary factors following can be used: grain size (median diameter), sorting, and maturity of rocks. Author determined a positive correlation link between median diameter of grains with porosity $\left(K_{\text {corr }}=0.56\right.$, Fig. $\left.7, a\right)$ and decimal logarithm of permeability $\left(K_{\text {corr }}=0.81\right)$. Critical value is $K_{\text {corr }}=0.211$ (while $p<0.05$ ). Poorly-sorted sandstones on the field of interest (unlike wellsorted) are characterized by lower porosity and permeability.

Author noted direct dependency of porosity on detritus quartz saturation that is expressed in porosity raise with quartz raise $\left(K_{\text {corr }}=0.51\right.$, Fig. $\left.8, b\right)$. It happens due to the fact a mineral forms a frame. Thus, mature sandstones have higher porosity, which affect reservoir properties positively.

Porosity is slightly decreased with a raise of feldspar and detritus rock saturation $\left(K_{\text {corr }}=\right.$ $=-0.63)$, which happens mainly in sandstones of $\mathrm{J}_{1}^{1}$ and $\mathrm{J}_{1}^{2}$.

Secondary factors of sandstone transformations are as follows: diagenesis and katagenesis processes, controlled by redox and acidbase conditions. During the study of thin sections mineral indicators of diagenesis and katagenesis stages of lithogenesis were found.

For the stages of diagenesis mineral composition transformations are common. That is caused mainly because of decomposition of organic matter and appearance of reducing environment [8]. Glouconite appears because of oxidation phase of diagenesis stage. Pyrite rash is associated with reducing phase. Formations of early katagenesis are largely inherited from 
diagenesis, but they keep them to a brand new qualitative basis [20]. At the stage of early katagenesis corrosion and dissolution of unstable minerals occur: the number of pores of dissolution of feldspars increases (Fig. 6) and rock debris that generally significantly affect reservoir properties. Debris feldspar and mica undergo a process of weak hydromicization and, as a consequence, turn to hydromica that negatively affects reservoir properties.
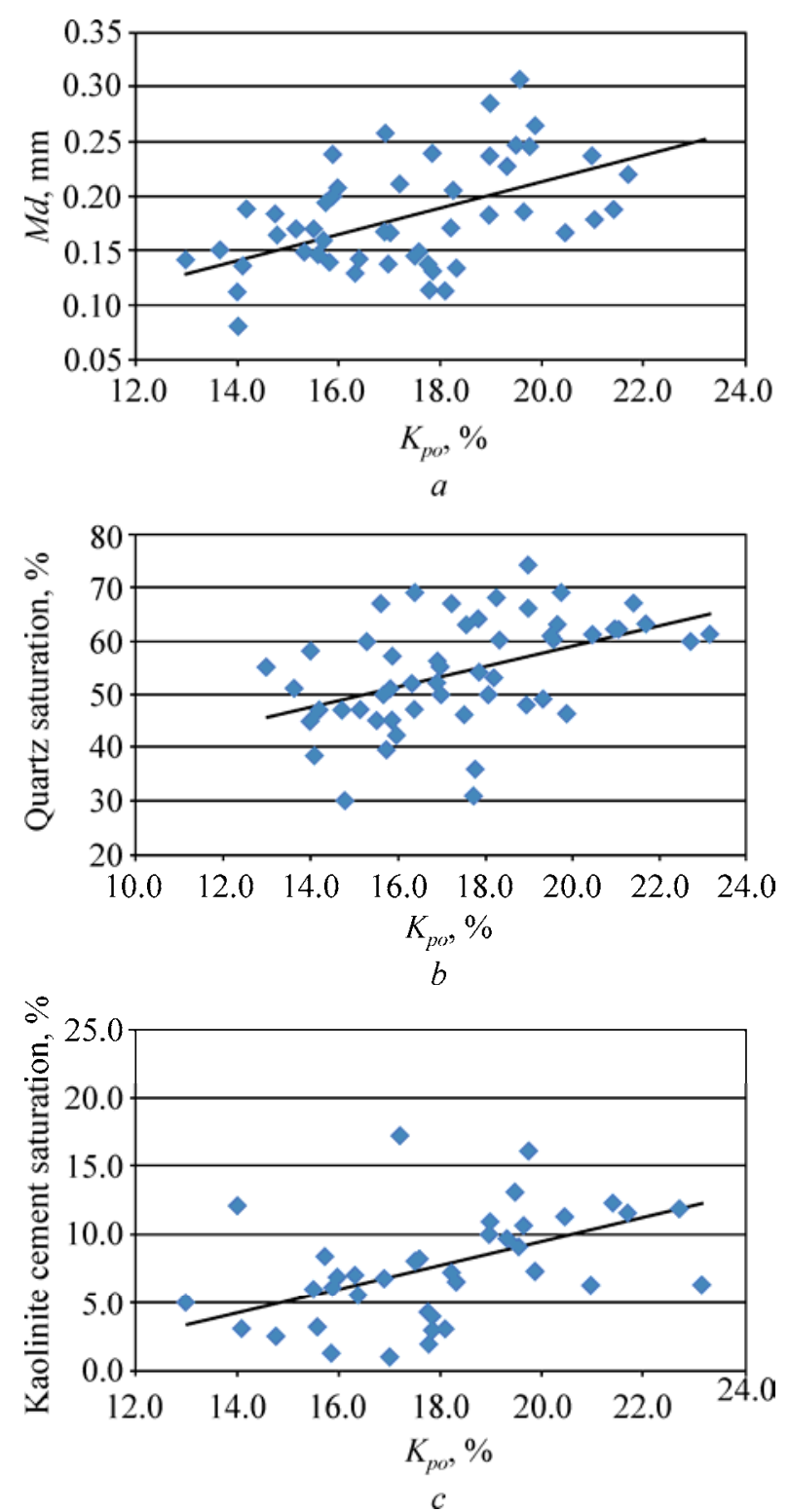

Fig. 7. Chart of a raltionship of $\left(K_{p o}\right)$ and: $a$ - grain median diameter $M d, K_{\text {corr }}=0.56$;

$b$ - detritus quartz saturation, $K_{\text {corr }}=0.51$;

$c$ - kaolinite cement saturation, $K_{\text {corr }}=0.48$
For the sandstones deep katagenesis is characterized by a wide development of regeneration of quartz hems (see Fig. 2). Moreover, structures such as dissolution and inception that occur under the pressure are formed. Those are conformal and incorporated structures, formed by indentation of detritus grains into others under the pressure (see Fig. 3). The feature of katagenesis stage is formation of big number of pore microcrystal kaolinite that creates micropores and positively affect reservoir properties of sandstones (see Fig. 5, 7, c).

\section{Conclusion}

Results of the study of rock-forming composition and cement of reservoirs $\mathrm{J}_{1}^{1}$ and $\mathrm{J}_{1}^{2}$ of Kazan oil-gas-condensate field (Tomsk region) are presented. The relationship between rock properties and primary (sedimentation) and secondary (post-sedimentation) factors is determined.

Comparative analysis of lithological features of $\mathrm{J}_{1}^{1}$ and $\mathrm{J}_{1}^{2}$ showes that they are significantly different to each other in terms of mineralogical composition (sediments of $\mathrm{J}_{1}^{1}$ reservoir are much mature that positively affect reservoir porosity). At the same time similar composition of rock debris points to constant source of rock ablation during sedimentation.

In addition to changes in the composition, sedimentation slowdown led to a slight increase in grain size of sandstone of $\mathrm{J}_{1}^{1}$ reservoir that led to improved sorting, change in the composition and cement type, which contributed to transformation of pore space structure. This was the main cause of porosity and permeability improvement of $\mathrm{J}_{1}^{1}$ reservoir.

Another cause of improved reservoir properties are secondary transformations, which are observed in form of increased share of kaolinite cement, kaolinite re-crystallization, partial dissolution of feldspars and increased number of 
intergranular interconnected pores. Deterioration of reservoir properties is associated with increased amount of siderite and hydromica cement in intergranular space. It should be noted that these conclusions are based on a qualitative assessment of rock thin section.

\section{References}

1. Zapivalov N.P., Minko V.A. Geologicheskoe stroenie Kazanskogo gazokondensatnogo mestorozhdeniia [Geological structure of Kazan gas-condensate field]. Neft i gaz Tiumeni: trudy ZapSibNIGNI. Tiumen, 1970, vol.6, pp.39-43.

2. Logvinenko N.V. Petrografiia osadochnykh porod s osnovami metodiki issledovaniia [Petrography of sedimentary rocks and basics of study methodology]. Moscow: Vysshaia shkola, 1984. $414 \mathrm{p}$.

3. Logvinenko N.V., Sergeeva E.I. Metody opredeleniia osadochnykh porod [Methods for determination of sedimentary rocks]. Leningrad: Nedra, 1986. 240 p.

4. Shvanov V.N. Peschanye porody i metody ikh izucheniia (raspredelenie, struktury, tekstury) [Sand rocks and study methods (distribution, structure, texture)]. Leningrad: Nedra, 1969. $270 \mathrm{p}$.

5. Shvanov V.N. Petrografiia peschanykh porod (komponent-nyi sostav, sistematika i opisanie mineralnykh vidov) [Petrography of sand rocks (composition, systematization and description of mineral types)]. Leningrad: Nedra, 1987. $269 \mathrm{p}$.

6. Frolov V.T. Litologiia [Lithology]: v 2 knigakh. Moscow: Izdatelstvo MGU, 1992, kniga 1. $336 \mathrm{p}$.

7. Frolov V.T. Litologiia [Lithology]: v 2 knigakh. Moscow: Izdatelstvo MGU, 1992, kniga 2. $430 \mathrm{p}$.

8. Rukhin L.B. Osnovy litologii [Lithology basics]. Leningrad: Nedra, 1956. 703 p.

9. Shutov V.G. Klassifikatciia peschanikov [Sandstones classification]. Litologiia i poleznye iskopaemye, 1967, no.5, pp.86-103.

10. Griffits Dzh. Nauchnye metody issledovaniia osadochnykh porod [Scientific methods of sedimentary rocks study]: perevod s angliiskogo. Moskow: Mir, 1971. 422 p.

11. Pettidzhon F.Dzh. Osadochnye porody [Sedimentary rocks]: perevod s angliiskogo pod redaktciei I.M. Simanovicha, P.P. Timofeeva. Moskow: Nedra, 1981. 752 p.

12. Harms J.C., Southard J.B., Walker R.G. Structures and sequences in clastic rocks: society of economic paleontologists and mineralogists short course. Tulsa, Oklahoma, 1982, no.9, 394 p.

13. Pettijohn P.J., Potter P.E. Atlas and glossary of primary sedimentary structures. New York: Springer, 1964. $370 \mathrm{p}$.

14. Pirson S.J., Pirson S.J. SP and EH curves as redoxomorphic logs. Geologic well log Analysis. Houston, Texas: Gulf., 1970. Pp.1-35.

15. Khanin A.A. Porody-kollektory nefti i gaza i ikh izuchenie [Study of reservoirs of oil and gas and]. Moscow: Nedra, 1969. 368 p.

16. Strakhov N.M. Osnovy teorii litogeneza [Basics of lithogenesis theory]. Moscow: Izdatel'stvo AN SSSR, 1960, vol.2, 274 p.

17. Sakhibgareev R.S. Vtorichnye izmeneniia kollektorov $\mathrm{v}$ protcesse formirovaniia i razrusheniia neftianykh mestorozhdenii [Secondary transformations of reservoirs in process of formation and destruction of oil fields]. Leningrad: Nedra, 1989. 260 p.

18. Sakhibgareev R.S. Osnovnye tipy vtorichnykh izmenenii kollektorov, proiskhodiashchikh $\mathrm{v}$ protcesse formirovaniia i razrusheniia zalezhei uglevodorodov, i ikh znachenie dlia optimizatcii geologorazvedochnykh rabot [The main types of secondary transformations of reservoirs during formation and destruction of hydrocarbon accumulation and their significance to optimize exploration work]. Vtorichnye izmeneniia kollektorov $v$ protcesse formirovaniia i razrusheniia 
zalezhei uglevodorodov $i$ ikh znachenie dlia optimizatcii geologorazvedochnykh rabot. Leningrad: Izdatelstvo VNIGRI, 1990. Pp.7-30.

19. Chernikov O.A. Preobrazovanie peschano-alevritovykh porod i ikh poristost [Transformation of sand and silt rocks and its porosity]. Moscow: Nauka, 1969. 120 p.

20. Iapaskurt O.V. Stadialnyi analiz litogeneza [Stage analysis of lithogenesis]: uchebnoe posobie. Moscow: Izdatelstvo MGU, 1994. 142 p.
21. Iapaskurt O.V. Stadialnyi analiz osadochnogo protcessa [Stage analysis of sedimentation]. Litologiia i poleznye iskopaemye, 2008, no.4, pp.364-376.

22. Iapaskurt O.V. Geneticheskaia mineralogiia i stadialnyi analiz protcessov osadochnogo porodo- i rudoobrazovaniia [Genetic mineralogy and stage analysis of processes of sedimentary formation of rocks and ores]: uchebnoe posobie. Moscow: ESLAN, 2008. 356 p.

\section{Список литературы}

1. Запивалов Н.П., Минько В. А. Геологическое строение Казанского газоконденсатного месторождения // Нефть и газ Тюмени: тр. ЗапСибНИГНИ. - Тюмень, 1970. - Вып. 6. С. 39-43.

2. Логвиненко Н.В. Петрография осадочных пород с основами методики исследования. - М.: Высшая школа, 1984. - 414 с.

3. Логвиненко Н.В., Сергеева Э.И. Методы определения осадочных пород. - Л.: Недра, 1986. - $240 \mathrm{c}$.

4. Шванов В.Н. Песчаные породы и методы их изучения (распределение, структуры, текстуры). - Л.: Недра, 1969. - 270 с.

5. Шванов В.Н. Петрография песчаных пород (компонентный состав, систематика и описание минеральных видов). - Л.: Недра, 1987. - 269 c.

6. Фролов В.Т. Литология: в 2 кн. - М.: Изд-во МГУ, 1992. - Кн. 1. - 336 с.

7. Фролов В.Т. Литология: в 2 кн. - М.: Изд-во МГУ, 1992. - Кн. 2. - 430 с.

8. Рухин Л.Б. Основы литологии. - Л.: Недра, 1956. - 703 с.

9. Шутов В.Г. Классификация песчаников // Литология и полезные ископаемые. - 1967. № 5. - С. 86-103.

10. Гриффитс Дж. Научные методы исследования осадочных пород: пер. с англ. - М.: Мир, 1971. - 422 с.
11. Петтиджон Ф.Дж. Осадочные породы / пер. с англ. под ред. И.М. Сима-новича, П.П. Тимофеева. - М.: Недра, 1981. -752 с.

12. Harms J.C., Southard J.B., Walker R.G. Structures and sequences in clastic rocks: society of economic paleontologists and mineralogists short course. - Tulsa, Oklahoma, 1982. - № 9. $394 \mathrm{p}$.

13. Pettijohn P.J., Potter P.E. Atlas and glossary of primary sedimentary structures. - New York: Springer, 1964. - $370 \mathrm{p}$.

14. Pirson S.J., Pirson S.J. SP and EH curves as redoxomorphic logs. Geologic well log Analysis. - Houston, Texas: Gulf., 1970. P. 1-35.

15. Ханин А.А. Породы-коллекторы нефти и газа и их изучение. - М.: Недра, 1969. $368 \mathrm{c}$.

16. Страхов Н.М. Основы теории литогенеза. - М.: Изд-во АН СССР, 1960. - Т. 2. $274 \mathrm{c}$.

17. Сахибгареев Р.С. Вторичные изменения коллекторов в процессе формирования и разрушения нефтяных месторождений. - Л.: Недра, 1989. - 260 с.

18. Сахибгареев Р.С. Основные типы вторичных изменений коллекторов, происходящих в процессе формирования и разрушения залежей углеводородов, и их значение для оптимизации геологоразведочных работ // 
Вторичные изменения коллекторов в процессе формирования и разрушения залежей углеводородов и их значение для оптимизации геологоразведочных работ. - Л.: Изд-во ВНИГРИ, 1990. - С. 7-30.

19. Черников О.А. Преобразование песчано-алеврито-вых пород и их пористость. - М.: Наука, 1969. - 120 с.

20. Япаскурт О.В. Стадиальный анализ литогенеза: учеб. пособие. - М.: Изд-во МГУ, 1994. - $142 \mathrm{c}$.
21. Япаскурт О.В. Стадиальный анализ осадочного процесса // Литология и полезные ископаемые. - 2008. - № 4. C. 364-376.

22. Япаскурт О.В. Генетическая минералогия и стадиальный анализ процессов осадочного породо- и рудообразования: учеб. пособие. М.: ЭСЛАН, 2008. - 356 с.

Please cite this article in English as:

Gabova K.V. Lithological features of coal-overlying accumulations of Upper Vasiugan formation of Kazan oil-gas-condensate field. Bulletin of PNRPU. Geology. Oil \& Gas Engineering \& Mining, 2016, vol.15, no.19, pp.122-131. DOI: 10.15593/2224-9923/2016.19.3

Просьба ссылаться на эту статью в русскоязычных источниках следующим образом:

Габова К.В. Литологические особенности продуктивных отложений надугольной пачки верхневасюганской подсвиты в пределах Казанского нефтегазоконденсатного месторождения // Вестник Пермского национального исследовательского политехнического университета. Геология. Нефтегазовое и горное дело. - 2016. - Т.15, №19. - С.122-131. DOI: 10.15593/2224-9923/2016.19.3 